\title{
Джон Ло как основоположник Столыпинского клуба
}

А.А. БАЛАБИН, кандидат экономических наук, Институт экономики и организации промышленного производства СО РАН, Новосибирский государственный технический университет. E-mail: balabin-a-a@mail.ru

В статье обсуждаются исторические корни идеи стимулирования экономики с помощью смягчения монетарной политики путем дополнительной денежной эмиссии. Рассматриваются экономические идеи и фактическое выполнение программы реформы денежного обращения Джона Ло - одного из финансовых деятелей Франции начала XVIII века. Суть реформы состояла в попытке замены денег, основанных на золото-серебряном стандарте, бумажными, а также в стимулировании хозяйственного развития Франции с помощью дополнительной денежной эмиссии. Проводятся аналогии с современными предложениями Столыпинского клуба по реформированию российской экономики.

Ключевые слова: денежно-кредитная политика, денежная эмиссия, бумажные деньги, государственный банк, государственные ценные бумаги, государственный долг, финансовая пирамида, Джон Ло, Франция, XVIII век, Столыпинский клуб, программа количественного смягчения

«Чуть настает вялость в торговле, в промышленности, чуть становятся капиталы редки, чуть только дела пойдут худо, как уже все кричат в один голос, что денег мало, деньги редки, и каждый утешает себя надеждой, что все пойдет хорошо стоит только увеличить количество денег. Странное заблуждение!»

И.К. Бабст. «Джон Ло, или финансовый кризис во Франции», 1852 г.

В 2017 г. исполнилось 300 лет с начала одного из самых впечатляющих экономических проектов. Его автором, вдохновителем и главным действующим лицом был Джон Ло (John Law of Lauriston), удачливый игрок в карты, ставший генеральным контролером (т.е. министром финансов) Франции.

Вообще говоря, в экономике редко предоставляется возможность провести «натурный» широкомасштабный эксперимент. А Джону Ло удалось воплотить свои финансовые идеи на территории целой европейской страны. Главная его идея состояла в стимулировании развития торговли, производства и заморских территорий Франции с помощью выпуска бумажных денег. Эта идея получила широкое развитие и научное обоснование в наше 
время, когда целый ряд развитых стран осуществляют программы количественного смягчения, которые как раз и состоят в целевой эмиссии денежных средств центральными банками для стимулирования развития национальной экономики ${ }^{1}$. Есть горячие сторонники этой идеи и в нашей стране.

Фигура Джона Ло по сей день привлекает значительное внимание за рубежом [2-6]. По мнению автора одного из американских учебников, он вошел в почетный список ста великих экономистов докейнсианского периода [7].

Из числа последних значительных работ о Джоне Ло на русском языке упомянем отдельные главы из книг [8-9]. Для изложения идей и действий Ло мы руководствовались в основном наиболее подробным описанием [10].

Напомним кратко «установочные данные» нашего героя. Сын преуспевающего ювелира и ростовщика Уильяма Ло, уроженец Эдинбурга, родился в 1671 г. Его отец умер, когда Джону было 14 лет, оставив ему значительное состояние и недавно приобретенный дворянский титул. Развлечения молодых людей того времени включали, в частности, азартные карточные игры, в которых Ло достиг большого мастерства. В 1691 г. Джон перебрался из столицы Шотландии в Лондон, но после дуэли в апреле 1694 г., на которой он убил своего противника, ему пришлось бежать в Голландию. В течение последующих лет он в качестве профессионального игрока в карты ездит по всей Европе, попутно знакомясь с финансовой деятельностью в Голландии, Германии, Италии и Франции.

\section{Экономические идеи Ло}

Отметим, что экономика как научное направление к тому времени окончательно еще не оформилась, и всякий грамотный и творчески мыслящий человек мог стать «экономистом», опубликовав свои соображения о возможных источниках обогащения. Одним из таких людей был и Джон Ло.

Наиболее известная работа Джона Ло под названием «Деньги и торговля, рассмотренные в связи с предложением об обеспечении нации деньгами» [11] была издана в 1705 г. в Эдинбурге. Она представляла собой проект для парламента Шотландии и содержала в обширной первой части теоретическое обоснование предлагаемых мероприятий. Основной посыл состоял в том, что «торговля и деньги находятся во взаимной зависимости; ценность

${ }^{1} \mathrm{C}$ некоторыми итогами программ количественного смягчения можно познакомиться в [1]. монеты изменяется, когда торговля падает, а когда количество монеты уменьшается, тогда падает торговля. Могущество и богатство заключаются и в возрастании запасов туземных и иноземных товаров, то и другое зависит от торговли, а торговля зависит от монеты...» (цит. по: [10. С. 75]).

Таким образом, по мнению Ло, наиболее верным средством стимулирования экономического развития является увеличение количества денег в стране. При этом если «настоящих», металлических денег не хватает, их можно создать искусственно, осуществив с помощью особого банка эмиссию бумажных денег (т.е. банкнот), не обеспеченных (или частично обеспеченных) запасами золота и серебра. Однако в надежности такого банка возникнут естественные сомнения. Чтобы убедить публику пользоваться банковскими билетами, Ло предлагает:

- обеспечить участие государства в капитале банка;

- выпускать билеты под обеспечение в виде земель, в том числе принадлежащих государству;

- разрешить принимать налоги и иные платежи в пользу государства билетами банка.

По мнению Ло, банкноты предпочтительнее звонкой монеты, которая должна быть вытеснена совместными усилиями государства (через прием налогов банкнотами) и эмиссионного банка (через кредитование банкнотами под низкий процент). Таким образом, новизна предложения Ло состояла именно в вытеснении из оборота металлической монеты банкнотами и увеличении на этой основе объемов производства и торговли.

Заметим, что кажущаяся путаница в обозначении предлагаемого Ло финансового инструмента (билеты, ноты, банкноты, бумажные деньги) объясняется тем, что в его время бумажные деньги были разновидностью долговых ценных бумаг. Простой вексель в английском языке до настоящего времени обозначается как promissory note, a простой вексель, выпущенный банком, - bank note (так возникло русское слово «банкнота»). Во французском языке простой вексель называется billet a'order (отсюда русские «билет», «банковский билет», «казначейский билет»). Для Ло и его современников банкноты представляли собой просто разновидность простых векселей со сроком платежа «до востребования», выпущенных по единому образцу государственным банком. 
Предложение об организации госбанка и выпуске банкнот под залог земель рассматривалось в парламенте Шотландии, но не было принято.

\section{Завязка}

Для того чтобы проект Ло имел шанс осуществиться, должны возникнуть особые условия. Такие условия сложились в 1710-х годах во Франции. Первое пребывание Джона Ло в Париже относится к 1708 г., когда он познакомился с Филиппом II, герцогом Орлеанским, племянником короля Франции Людовика XIV.

Франция тогда переживала не лучшие времена. Длительная Война за испанское наследство (закончилась Утрехтским миром в 1713 г.), прихоти «короля-солнца» и его приближенных сильно подкосили финансы государства. Будущие налоги были получены и истрачены королевским двором на несколько лет вперед. Практика государственных займов (так называемых рент) приобрела угрожающие масштабы. Государственное учреждение, ответственное за займы (Касса займов), первоначально привлекавшее деньги под 5\% годовых, вынуждено было поднять доходность рент (сегодняшний аналог - гособлигации) до 8\%, а в 1705 г.до 10\% годовых [9. С. 167]. Продавались и пожизненные ренты, по которым проценты должны были выплачиваться до смерти их держателя.

С помощью векселей и кассы брали займы отдельные государственные ведомства и даже их подразделения, конкурирующие друг с другом на долговом рынке. Другим немаловажным источником доходов служила продажа государственных должностей. Чрезвычайный источник пополнения финансов составляли манипуляции государства с содержанием драгоценных металлов в монете (порча монеты). Несмотря на это, текущий дефицит королевского бюджета в 1708 г. превышал 686 млн ливров, притом, что регулярные госдоходы (поголовная подать и десятина) давали только 75 млн ливров ежегодно [10. С. 21-22].

В 1715 г. умирает Людовик XIV, и регентом при малолетнем короле Людовике XV становится герцог Орлеанский.

Финансовые проблемы Франции к тому времени только усугубились. Текущий дефицит королевского бюджета увеличился до 1 млрд ливров. Общая величина госдолга достигла
2800 млн ливров, из которых 1068 млн ливров приходилось на бессрочные ренты, а 830 млн - на залоги по проданным должностям [9. С. 168].

Много позже Людовик XV так охарактеризовал положение дел в стране: «При вступлении на престол мы не нашли ни в королевской казне, ни у сборщиков никаких средств для самых необходимых издержек; напротив, мы нашли, что государственные имущества были отчуждены, что государственные доходы почти поглощены бесчисленными обязательствами и созданными должностями, что обыкновенные подати были заранее истрачены, что недоимки накопились за многие годы, что всякого рода счеты были в совершенном беспорядке; кроме того, мы нашли массу билетов, обязательств и авансовых ассигновок разного рода на такие суммы, что едва ли возможно сделать им общий перечень...» (цит. по: [10. С. 25]).

Регент короля герцог Орлеанский и новый глава финансового ведомства герцог де Ноайль предприняли чрезвычайные меры для поиска новых источников доходов. Были несколько уменьшены расходы на содержание двора, сокращена численность армии, сняты ограничения на торговлю хлебом. Была объявлена перечеканка монеты со снижением содержания в ней драгметаллов, принудительно реструктурированы ренты Кассы займов со снижением процентных ставок по ним. Была списана часть текущего долга госучреждений, другая часть переоформлена в государственные 4\%-е обязательства (billets d'Etat). Были введены чрезвычайные процедуры и конфискации через особую Судебную камеру, действовавшую в 1716 - начале 1717 гг. Указанные меры позволили несколько выправить текущую финансовую ситуацию, но одновременно привели к чрезвычайно угнетенному состоянию дел во всей Франции. Вера в незыблемость обязательств государства, стабильность золотого и серебряного стандарта и в правосудие была окончательно утеряна.

\section{Кульминация}

Именно в этот смутный период идеи Джона Ло стали особенно привлекательными. Сразу после смерти Людовика XIV Ло продает все свои имения в Шотландии и поселяется в Париже. 
Новые встречи с регентом закончились внесением проекта Ло на обсуждение финансового совета под председательством де Ноайля в октябре 1715 г. Предполагалось создание банка с государственным участием, который эмитировал бы от своего лица банкноты, а также от имени государства принимал платежи и производил платежи за товары и услуги банкнотами или монетой.

Выпускаемые банкноты должны были свободно и немедленно обмениваться банком по желанию их предъявителей на монету. Участие банка в «реальной экономике» ограничивалось бы только приемом к учету векселей третьих лиц. Отметим, что в отличие от предшествующих предложений Ло, идея «твердого» залога в виде земли для соответствующего выпуска банкнот госбанком отсутствовала.

Проект Ло был отвергнут большинством совета со ссылкой на недоверие общества к государству как будущему соучредителю банка.

После этого Ло решает учредить частный Генеральный банк и в мае 1716 г. получает разрешение. Уставный капитал составлял 1200 акций по 5000 ливров каждая (т.е. 6 млн ливров), причем $25 \%$ должно быть оплачено монетой, а оставшуюся можно было внести billets d'Etat по номиналу (притом, что их рыночный курс в это время составлял 40\% от номинала). В состав учредителей вошли Ло, регент и приближенные к нему лица [10. С. 96].

Устав банка разрешал выпуск банковских билетов, уплачиваемых по предъявлении, прием денежных депозитов, выдачу векселей с платежом по предъявлении на провинцию и на иностранные банкирские дома. Одновременно было сильно ограничено проведение активных операций, в частности, запрещалась выдача ссуд.

Немаловажным обстоятельством было то, что банку было разрешено вести счета в особых серебряных экю, которые подразумевали учет не только количества монеты, но и содержание в ней золота и серебра. Это давало решающее преимущество: в условиях частой перечеканки (и порчи) монеты государством банк обязывался выдавать владельцу то количество драгоценного металла, которое он внес на счет.

Поначалу деятельность банка характеризовалась обязательностью, скромными размерами операций и низкими ставками учета векселей. Посильную помощь оказывали учредители. Так, циркуляры генерального контролера в октябре 1716 г. рекомендовали, а в апреле 1717 г. - обязывали принимать банкноты банка для уплаты налогов и пошлин. И наконец, в декабре 1718 г. при горячей поддержке регента произошла национализация банка: частные акционеры продали, а министерство финансов - выкупило 1000 акций банка за 5 млн ливров [9. С. 178]. Конечно, физические лица, учредившие банк, хорошо заработали, первоначально внеся в капитал обесцененные гособлигации, а получив «живые» деньги. Банк получает новое название - Королевский (Banque Royal).

Однако основное устремление Джона Ло состояло всё же в широком внедрении выпущенных им банкнот в хозяйственной жизни Франции. Создания банка было недостаточно, требовался большой проект, который стимулировал бы спрос на банкноты. И такой проект был найден - освоение потенциальных богатств Луизианы - колонии Франции на Североамериканском континенте. Следует отметить, что попытки колонизации этих территорий предпринимались и раньше, однако ощутимых успехов, с учетом состояния метрополии, не принесли. В 1717 г. Ло учредил акционерную Компанию Запада с огромным уставным капиталом в 100 млн ливров (200 тыс. акций по 500 ливров). Взносы принимались от неограниченного круга лиц обесцененными billets d'Etat (по номиналу), банкнотами банка, монетой.

Конечно, следовало убедить публику в перспективности Компании, продемонстрировав доходность вложений в её акции. Для этого в середине 1718 г. были выплачены промежуточные дивиденды. Кроме того, инвестор мог купить акции в рассрочку, заплатив 20\% стоимости, а остальное внести в течение последующих пяти месяцев.

Первичное размещение акций завершилось 31 декабря 1718 г. После того как уставный капитал был сформирован, по договоренности с министерством финансов сотни тысяч ливров, собранных в уставный капитал Компании, были обменены на ежегодную государственную ренту в 4\% годовых. Она должна была обеспечиваться за счет будущих бюджетных поступлений пошлин, почтовых и табачных доходов. Таким образом, произошла частичная консолидация размытого, неуправляемого госдолга, основным держателем которого становится Компания. 
Дальнейшее развитие Компании пошло по пути приобретения ей все новых откупов у государства (монополии на торговлю табаком, торговлю с заморскими территориями, право чеканки монеты). Венцом стал генеральный откуп на сбор налогов и акцизов в августе 1719 г. Схема не предусматривала использования денежных средств: права оплачивались акциями самой Компании или же на них обменивались акции поглощаемого предприятия. В процессе проведения поглощений Компания неоднократно переименовывалась: сначала в Компанию Миссисипи, затем в Компанию Индий. Интерес к ней подогревался рекламными брошюрами о несметных богатствах Луизианы [10. С. 139].

Все указанные действия преследовали цель усилить интерес публики к акциям компании, вызвать рост их курсовой стоимости (к примеру, выплачивались промежуточные дивиденды, вводились отсрочки по оплате акций новых выпусков, распускались разнообразные слухи и т.д.). Так сложилась двуединая конструкиия (банк, эмитирующий дополнительные билеты, и компания, выпускающая дополнительные акиии), которую Ло назвал впоследствии своей Системой.

В течение 1719 г. было осуществлено еще шесть выпусков акций общим объемом 424 тыс. шт. Акции более поздних выпусков можно было также приобрести в рассрочку, но только тем, у кого были предыдущие выпуски. Первичное размещение новых выпусков акций проходило уже по рыночному курсу. Так, второй выпуск продавался за 550 ливров (т.е. с премией 50 ливров к номиналу), третий - за 1000 ливров, четвертый и последующие за 5000 ливров. Оплата производилась уже не гособлигациями, а только монетой или банкнотами Королевского банка.

Параллельно с выпусками акций производилась эмиссия банкнот. В 1718 г. выпуск бумажных денег составил всего 40 млн ливров, в 1719 г., когда банк стал Королевским,- 1 млрд ливров, причем выпуск банкнот, выраженных в серебряных экю, был прекращен. Максимальный объем банкнот, находившихся в обращении, был достигнут в мае 1720 г. (около 2,2 млрд ливров по номиналу) [12. С. 25].

К концу 1719 г. акции Компании поднялись в цене до 11 тыс. ливров, в начале января 1720 г. была достигнута максимальная цена - 18 тыс. ливров за акцию. Наконец, в феврале 1720 г. произошло слияние Королевского банка и Компании Индий, а сам
Джон Ло был назначен генеральным контролером Франции. Образовалось гигантское государственное учреждение, в котором под управлением одного человека оказались не только монетарные, коммерческие, фискальные органы и доходы государства, но и частные капиталы королевской семьи и верхушки дворянства.

Повлияла ли накачка денежными суррогатами на хозяйственную жизнь Франции? Поначалу - да. Перечислим некоторые из положительных эффектов.

- Ставки по учету векселей и ставки кредитования существенно снизились - с 25-34\% годовых до 5-7\% в 1718-1719 гг., что оживило все сферы хозяйственной деятельности.

- Был централизован сбор налогов через одного генерального откупщика (Компания Ло). Снижены и упорядочены пошлины на ряд товаров (хлеб, сыр, вино, сало, некоторые ткани), освобождена от пошлин торговля табаком внутри страны (однако ввоз табака контролировался Компанией).

- Был консолидирован и упорядочен государственный долг, удешевлено его обслуживание. Продажа акций за billets d'Etat позволила сосредоточить $3 / 4$ госдолга в Компании, в последующем они были обменены на единую ренту с доходностью 4\% годовых.

- Оживились предприятия по производству предметов длительного пользования, в том числе роскоши. В 1719 г. число мануфактур, по официальным сведениям, выросло на 60\% [10. С. 190].

- Ремонтировались некоторые дороги, предпринято строительство новых и расширение старых водных каналов.

- Ускорился оборот недвижимости (а следом подтянулось и строительство), увеличились продажи земельных угодий и замков.

- Получило определенный толчок развитие французской колонии в Луизиане, оживилась экспедиционная деятельность.

В целом реформы, предпринятые Ло, способствовали временной расшивке «узких мест» французской экономики, в том числе главного из них - королевского бюджета. В 1715 г. дефицит бюджета Франции (включая расходы по обслуживанию долга) составлял 134,5 млн ливров, в 1716 г. - 163,1 млн, в 1717 г. 170 млн ливров. В 1719 г., когда развернулась работа банка и Компании Ло, дефицит уменьшился до 64,2 млн, а в 1720 г. до 60,8 млн ливров [12. С. 40]. 


\section{Финал}

К сожалению, финансовый триумф был недолгим. Сам Ло исчислял доходы компании за 1720 г. только в 91 млн ливров (государственная рента - 48 млн, прибыль от генерального откупа -12 млн, от табачной монополии -6 млн, от взимания прямых налогов -1 млн, от чеканки монеты - 12 млн, от торговли - 12 млн ливров) [10. С. 209-210]. Теоретически Компания могла стать прибыльной только через много лет. Очевидно, что её текущие доходы, разделенные между держателями акций (получилось бы 146 ливров на акцию), не могли обеспечить приемлемую доходность. Акционер, приобретший акцию в 1719 г. за 10 тыс. ливров, смог бы получить максимум 1,46\% годовых. А за вычетом текущих расходов Компании - еще меньше. Вложения в акции давали меньше, чем выпущенные ранее 4\%-е облигации государства. И это послужило первым толчком к смене настроений спекулянтов. Цена акций покатилась вниз.

Были предприняты различные меры для поддержания курса акций Компании и банкнот Королевского банка (в частности, требование платить подати только банкнотами, организация регулярной скупки акций самой Компанией, ограничение сумм, которыми можно оплачивать крупные покупки с помощью металлической монеты, запрет на использование золота и серебра во внешней торговле всем, кроме Компании, и др.).

За счет этих мер удалось до апреля 1720 г. поддерживать цену акций на уровне 9 тыс. ливров, однако в мае она скатилась до 6 тыс., а к началу 1721 г.-до 1 тыс. ливров [12. С. 16]. Конечно, речь здесь идет о ценах, выраженных не в металлической монете, а в банкнотах Королевского банка. Продать акции за монету было уже невозможно. Исключение составляли знатные лица из королевской семьи, чьи указания Ло был вынужден выполнять.

Одновременно со сверхэмиссией банкнот сильно росли и цены - как на предметы роскоши, так и на повседневные продукты (хлеб, мясо, лук и т.д.). Дрова и уголь, например, подорожали более чем вдвое, свечи поднялись в цене с 1,6 до 9 ливров, кофе - с 2,5 до 18 ливров [10. С. 250]. Повсеместно (особенно в провинции) начали устанавливаться различные цены на товары, в зависимости от того, предполагалась ли уплата монетой или банкнотами.
Некоторые макроэкономические показатели Франции приведены на рисунке. Из них следует, что в 1715-1718 гг. цены и уровень жизни были стабильными. Со второй половины 1719 г. (период ускоренной эмиссии бумажных денег) цены резко идут в рост, увеличиваясь в два раза по сравнению с 1717 г. Номинальные доходы в 1719 г. повышаются тем же темпом, в связи с чем реальные доходы сравнимы с предшествующими годами. Однако в 1720 г. из-за резкого роста цен, опережающего номинальные доходы, реальные доходы снижаются до уровня 1711-1712 гг. В целом динамика индекса реальных доходов почти зеркально отражает индекс товарных цен.

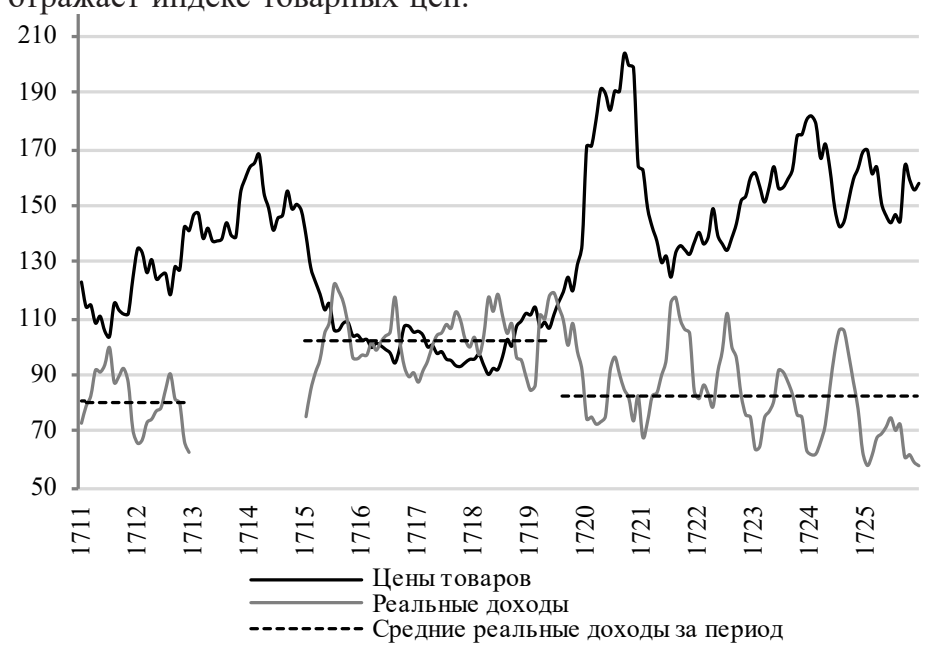

Источник: составлено на основе числовых данные в [13. С. 51,53].

Индексы цен товаров и реальных доходов во Франции в 1711-1725 гг. (на конец месяца, средняя цена в 1716-1917 гг.=100\%)

Сравнение усредненных реальных доходов позволяет выявить три различных временных отрезка: 1711 г. - середина 1715 г., середина 1715 г. - середина 1719 г., и середина 1719 г. - 1725 г.

Повышение реальных доходов с середины 1715 г. до середины 1719 г. было связано с окончанием Войны за испанское наследство, проведением чрезвычайных мероприятий по стабилизации бюджета Франции де Ноайлем и первыми эффектами выпуска банкнот Генеральным (позже - Королевским) банком. Однако 
последующие неумеренные эмиссии в 1719 г. привели к резкому росту цен, дальнейшему расстройству государственных финансов, падению уровня жизни почти до состояния военного времени. Таким образом, положительный эффект от монетарного (количественного) смягчения в экономике Франции длился не более полутора лет.

В мае 1720 г. Ло отстраняют от дел и снимают с должности генерального контролера. В ходе дальнейшей ревизии устанавливается наличие в банке 21 млн ливров монетой, 28 млн - в слитках и 240 млн - в векселях [10. С. 323]. Таким образом, высоколиквидные активы Королевского банка составили 289 млн ливров (при объеме банкнот в обращении на 2,2 млрд ливров).

Паника и гнев охватили граждан, оставшихся с обесцененными акциями и банкнотами на руках. В июле 1720 г. в Париж были введены войска. Джон Ло сначала был удален из Парижа в свое поместье, а потом, в декабре 1720 г., тайно покинул Францию. До конца своей жизни (а он умер в 1729 г. в Венеции) Ло остался верен своим идеям. Монтескье, посетивший его в Италии, нашел в нем «того же человека, преисполненного проектов, с головой, занятой вычислениями, соображениями о монете и денежных знаках» (цит. по: [10. С. 351]).

Неудачу реформ Ло можно объяснить несколькими обстоятельствами. Во-первых, начатые им «инвестиционные проекты» имели долгосрочный характер и не могли обеспечить немедленного прироста доходов государства и приемлемой доходности вложений для «инвесторов» в краткосрочной перспективе. Более того, сами эти проекты не имели сколько-нибудь серьезного обоснования. Во-вторых, мобилизованные средства в значительной части были потрачены на непроизводственное потребление правящей верхушки общества - приобретение предметов роскоши и объектов недвижимости. Сам Ло за время своего взлета приобрел несколько поместий в окрестностях Парижа.

Лишь значительно позже, с развитием экономики, было осознано непонятое Ло различие между деньгами как мимолетным средством обмена и деньгами-капиталом, приобретающим определенную производительную форму и создающим материальные богатства страны. Ни один банк не может «производить» капитал, он может лишь аккумулировать его свободные излишки и передавать их во временное пользованием третьим лицам. Если экономика страны характеризуется низкой производительностью труда, население бедно, а значительная часть валового внутреннего продукта тратится на непроизводственное потребление, это неизбежно означает сильные ограничения в аккумулировании дополнительного капитала и его «дороговизну».

Уже в наше время основатель количественной теории денег М. Фридман приводит наглядный пример с разбрасыванием денег с вертолета над неким городком [14. Гл. 2]. Он показывает, что в результате «денежного дождя» жители городка, производя всё то же количество продукции и услуг, не станут жить лучше; это попросту приведет к росту цен. Джон Ло устроил целый «денежный ливень», не слишком заботясь о развитии производительных сил Франции. Результат был именно таким, какой и следовало ожидать.

\section{Дежавю}

Первое, что приходит в голову гражданам нашей страны при ознакомлении с «достижениями» Ло,- это финансовая пирамида МММ-образца 1994 г., или так называемая «пирамида ГКО», приведшая к дефолту и финансовому кризису 1998 г. Не вдаваясь в подробности, скажем, что аналогии эти будут поверхностными, поскольку в обоих вышеуказанных случаях речь не шла о внедрении целостной системы взглядов в экономическую жизнь, и задача по стимулированию хозяйственной деятельности не ставилась.

Вместе с тем знакомство со взглядами некоторых современных российских сторонников денежного стимулирования экономики (особенно из среды собственников и директоров компаний реального сектора) невольно заставляет вновь вспомнить давние идеи Джона Ло. Есть и научная поддержка этих взглядов в лице Столыпинского клуба и недавно созданного им Института экономики роста им. П.А. Столыпина. Опубликована и широко обсуждается среднесрочная программа социально-экономического развития России до 2025 г. «Стратегия роста» [15].

Удивительным образом рекомендации по оживлению российской экономики напоминают предложения Джона Ло (см. таблицу), особенно в части предполагаемого источника финансирования. 
Сравнительная характеристика программ Джона Ло и Столыпинского клуба

\begin{tabular}{|l|l|l|}
\hline \multicolumn{1}{|c|}{ Характеристика } & \multicolumn{1}{|c|}{ Система Джона Ло } & \multicolumn{1}{|c|}{ “Стратегия роста» [15] } \\
\hline Цель & Оживление торговли и ремесел & $\begin{array}{l}\text { Увеличение темпов роста реаль- } \\
\text { ногосектораэкономики, в первую } \\
\text { очередь малого и среднего } \\
\text { бизнеса [С.19] }\end{array}$ \\
\hline Направление инвестиций & $\begin{array}{l}\text { Проекты Компании Миссисипи } \\
\text { (позже - Компания Индий), } \\
\text { недвижимость, развитие путей } \\
\text { сообщения }\end{array}$ & $\begin{array}{l}100 \text { «якорных» инвестиционных } \\
\text { проектов, поддержка малого } \\
\text { и среднего бизнеса, стимулиро- } \\
\text { вание экспортных производств, } \\
\text { жилищне строительство [С. 22, } \\
\text { 24,29] }\end{array}$ \\
\hline $\begin{array}{l}\text { Финансовый институт для под- } \\
\text { держки роста }\end{array}$ & $\begin{array}{l}\text { Первоначально - частный, а за- } \\
\text { тем - государственный (Коро- } \\
\text { левский банк) }\end{array}$ & $\begin{array}{l}\text { Банк России и банки с госуча- } \\
\text { стием [С. 27-28] }\end{array}$ \\
\hline Основной источник средств & $\begin{array}{l}\text { Необеспеченная целевая денеж- } \\
\text { ная эмиссия }\end{array}$ & $\begin{array}{l}\text { Необеспеченная целевая денеж- } \\
\text { ная эмиссия [С. 27-28] }\end{array}$ \\
\hline Налоговая политика & $\begin{array}{l}\text { Упорядочение и смягчение на- } \\
\text { логов }\end{array}$ & $\begin{array}{l}\text { Упорядочение и смягчение на- } \\
\text { логов [С. 31] }\end{array}$ \\
\hline Финансовая политика & $\begin{array}{l}\text { Существенное и быстрое сниже- } \\
\text { ние ставок учета векселей }\end{array}$ & $\begin{array}{l}\text { Существенное и быстрое сниже- } \\
\text { ние ставок кредитования [С. 25] }\end{array}$ \\
\hline Социальная политика & $\begin{array}{l}\text { Увеличение занятости населе- } \\
\text { ния, обогащение всех сословий } \\
\text { засчетростакурсовойстоимости } \\
\text { акций Компании }\end{array}$ & $\begin{array}{l}\text { Создание современных рабочих } \\
\text { мест, достижение высокого } \\
\text { уровня потребления [С. 7, 35] }\end{array}$ \\
\hline
\end{tabular}

Источник: составлено автором на основе [10], [15].

Приведенные в таблице предложения развиваются и обосновываются в многочисленных приложениях к презентации программы «Стратегия роста», а также разъясняются в средствах массовой информации (см., например [16]).

Некоторые идеи авторов совпадают с действиями Ло до деталей. К примеру, выше описывался предпринятый для привлечения средств французов выпуск Генеральным банком особых банковских билетов, номинированных в «серебряных» экю. В программе «Стратегия роста» мы находим аналогичное предложение - организовать для населения выпуск особых «индексных облигаций, номинированных в рублях, с купоном, привязанным к курсу рубля к корзине валют» [15. С. 25].

Основным источником средств в программе выступает Банк России: предполагается, что объем ежегодных денежных вливаний должен составить 1,5 трлн руб. [15. С. 17, 28]. Отметим, что в настоящее время прямое кредитование каких-либо организаций (в том числе органов власти), за исключением кредитных организаций и Агентства по страхованию вкладов, со стороны Банка России не допускается [17. Ст. 22, 46] $]^{2}$. Поэтому для «количественного смягчения» предлагается использовать ряд таких организаций, как ВЭБ, банки с госучастием, Российское агентство по страхованию экспортных кредитов и инвестиций (ЭСКАР) и др.

Одновременно к Банку России выдвигается множество требований [15. С. 27]:

- перейти к планомерному снижению ключевой ставки;

- дофинансировать существующие и создать новые институты развития;

- запустить новые специальные инструменты рефинансирования кредитов Банком России в системе проектного, торгового финансирования;

- разработать систему обеспечения Банком России суверенных гарантий Правительства РФ;

- использовать специализированные механизмы рефинансирования Банка России для кредитования малого и среднего бизнеса;

- пересмотреть систему оценки рисков коммерческих банков.

Особые опасения внушает поставленный на повестку дня вопрос о пересмотре системы оценки рисков (под ним в программе «Стратегия роста» понимается существенное снижение требований Банка России по нормированию и резервированию при выдаче коммерческих кредитов). Отметим, что Джон Ло не видел особой проблемы в рискованном кредитовании: «Чем больше банк раздает ссуд, тем больше увеличивает он количество монеты, приносящей доход стране, потому что при этом дается занятие большему числу рук, торговля расширяется, займы становятся легче и дешевле, и, наконец, сам банк наживает барыши», при этом «верная выгода, которая этим достигается, значительно перевешивает опасность, хотя бы при этом банк раз в два или три года приостанавливал свои платежи» (цит. по [10. С. 80-81]). Таким образом, банковский дефолт раз в 2-3 года его не пугает.

${ }^{2}$ Отметим, что во времена Джона Ло это общепринятое в настоящее время правило было неизвестно. Исторически возникновение первых государственных банков (Банка Швеции, Банка Англии, да и Королевского банка во Франции) было связано именно с желанием государства получить доступ к дополнительным источникам кредитования. 
Авторы «Стратегии роста», как и Ло, считают, что банковские риски в их стратегии есть, однако «риски ничего не делать - несравненно выше». Они предлагают более «цивилизованный» путь ограничения рисков: создать «Банк плохих долгов», который, по-видимому, и должен абсорбировать негативные последствия резкого расширения кредитования [15. С. 27]. Здесь же высказывается идея о страховании банковских вкладов юридических лиц. Естественно, что при таком способе решения проблем многолетние усилия Банка России по налаживанию системы оценки банковских рисков и очистке банковской системы от ненадежных банков становятся ненужными. Зачем налаживать риск-менеджмент, если коммерческие банки станут передавать безнадежные долги своих заемщиков в общую «мусорную корзинку»? Ведь в этом случае потери от рисков ложатся не на конкретных участников хозяйственного процесса, осуществляющих свою деятельность на свой страх и риск, а на общество в целом (как бы ни назывался конкретный госорган, компенсирующий потери).

На наш взгляд, ключевая ошибка в обосновании финансовых источников реализации программы «Стратегия роста» состоит в том, что имеющиеся кредитные риски рассматриваются ее авторами не как объективно существующие, а как искусственно вменённые Банком России. По их мнению, в рисках виновата не зыбкость отечественной финансовой среды предпринимательства (в том числе малого и среднего), не ненадежность исполнения взаимных обязательств, а излишняя строгость инструкций. При этом как-то забывается, что именно анализ практики кредитования и статистики дефолтов, выявление случаев недобросовестного поведения заемщиков, менеджмента и собственников банков приводят к соответствующим новациям и ограничениям в нормативных документах. А высокие ставки кредитования и резервирования во многом связаны с необходимостью компенсации потерь от рисков. Конечно, можно закрыть глаза на эти риски, но от этого они никуда не исчезнут и через некоторое время обязательно проявятся в виде убытков.

Выше мы отмечали, что итоги осуществления Системы Ло в первый год были весьма неплохи, а люди (и не только верхушка общества) чувствовали себя богаче. Можно с известной долей уверенности предположить, что аналогичными будут и результаты исполнения «Стратегии роста»- получит развитие ряд избранных производств, оживится спрос на инвестиционные товары, произойдет «расшивка узких мест», смягчатся дисбалансы за счет использования незагруженных мощностей и реализации производственных запасов, увеличится заработная плата. Но через год-полтора последствия могут быть не просто неблагоприятными, но и катастрофическими. Как это не раз происходило в истории.

Вырисовывается и круг заинтересованных в программе Столыпинского клуба лиц. С одной стороны, это крупные банки с государственным участием, через которые пойдет денежный поток от Банка России (в первую очередь у них появляется возможность расширить рамки и объемы кредитования, не слишком заботясь о рисках, уповая при этом на «Банк плохих долгов» и на «политику предупреждений и оздоровления»). С другой стороны, это некоторая выбранная «якорной» часть бизнесменов, которые тоже, не слишком заботясь о залогах, получат защиту через специализированные механизмы рефинансирования кредитов Банком России и страховку своих хозяйственных рисков. Есть и более широкие слои общества, которых привлекает потенциальная возможность чудесного оживления экономики путем манипуляций, которые за них должен сделать Банк России (вспомним наших сограждан - активных участников и защитников МММ).

Понятно, что исполнители «мягкой» кредитно-денежной политики в случае неудачи будут кивать при этом на решения политических деятелей, а те - говорить, что они преследовали самые благие цели, что их (политиков) не так поняли, недостаточно (активно, непоследовательно, несвоевременно, частично и т.п.) проводили в жизнь их смелые идеи. Не хотелось бы наступать на грабли еще раз.

\section{Литература}

1. Балабин А.А. Плоды количественного смягчения //ЭКО.- 2016.№ 6.- C. 50-67.

2. Murphy A. John Law: Economic Theorist and Policy-Maker - Oxford: Clarendon Press, 1997.

3. Gleeson J. Millionaire: The Philanderer, Gambler, and Duelist Who Invented Modern Finance - New York: Simon \& Schuster, 2000.

4. Garber P. Famous First Bubbles: The Fundamentals of Early Manias.MIT Press, 2000. 
5. McCall C. Cash, Credit and Chaos: A Brief History of the Life and Work of John Law (1671-1729), the Father of Credit Systems (Lesser Known Heroes) - Matlock, UK: Solcol, 2007.

6. Adams G. Letters to John Law - Washington: Newton Page, 2012.

7. Блауг М. 100 великих экономистов до Кейнса - СПб.: Экономикус, 2008.

8. Аникин А. В. История финансовых потрясений: российский кризис в сфере мирового опыта.- 3-е изд.- М.: Олимп-бизнес, 2009.

9. Моисеев С. Р. История центральных банков и бумажных денег.- М.: Вече, 2015. URL: https://www.cbr.ru/bankmuseum/files/history_central_ banks.pdf

10. Горн Й. Джон Ло. Опыт исследования истории финансов /Пер. с нем. И. Шипова, с предисловием Н.Х. Бунге.- СПб.: Тип. А.С. Суворина, 1895.

11. Law J. Money and trade considered: with a proposal for supplying the nation with money. First published at Edinburgh 1705.- Glasgow: R. \& A. Foulis, 1750. URL: https://openlibrary.org/books/OL20425133M/ Money_and_trade_considered

12. Velde F. Government Equity and Money: John Law's System in 1720 France. FRB of Chicago Working Paper № 2003-31, December 2003. URL: http://www.heraldica.org/econ/law.pdf

13. Hamilton E. Prices and Wages at Paris under John Law's System // The Quarterly Journal of Economics.- 1936.- Vol. 51.- № 1.- P. 42-70.

14. Фридмен М. Количественная теория денег - М.: Эльф пресс, 1996.

15. Среднесрочная программа социально-экономического развития России до 2025 года «Стратегия роста» // Ин-т экономики роста им. П.А. Столыпина. URL: http://rost.institute/wp-content/ uploads/2017/10/strategiya-rosta-28.02.2017.pdf (дата обращения: 27.07.2017).

16. Судебную реформу за один день не проведешь, а налоги изменить можно. Интервью с уполномоченным при Президенте России по правам предпринимателей Б. Ю. Титовым//Ведомости.- 2017.- 14 февр. 17. Федеральный закон от 10.07.2002 N86-Ф3 (ред. от 18.07.2017) «О Центральном банке Российской Федерации (Банке России)» // СПС «КонсультантПлюс». 